DOI: https://doi.org/10.24144/2409-6857.2018.1(51).170-175

УДК 330.3

\title{
Цанько О.О.
}

\section{АНАЛІЗ СТАНУ ІНВЕСТИЦЙНОГО СЕРЕДОВИЩА ЛЬВІВСЬКОЇ ОБЛАСТІ}

\begin{abstract}
Проаналізовано ключові аспекти інвестиційних процесів у Львівської області. Досліджено характерні чинники формування інвестиційного середовщща Львівщини та ї̈ інвестиційної привабливості. Визначено регіональні особливості, щзо сприяють залученню іноземного капіталу в економіку області, а саме: близькість до державного кордону з СС, кадровий потенціал, забезпеченість мінеральними, земельними, водними ресурсами та хороший доступ до них, розвинена інфраструктура. Виконано аналіз статистичних показників, щчо пов'язані із діяльністю іноземних інвесторів в області загалом, так $і$ на території окремих районів. Розглянуто питання діяльності індустріальних парків та виявлено основні переваги від їхнього функціонування. Обтрунтовано необхідність активізації промоції потенціалу регіону та використання інших методів міжрегіонального співробітництва з метою залучення іноземного капіталу.
\end{abstract}

Ключові слова: інвестииії, інвестииійний клімат, інвестиційна політика, регіональна економіка.

Постановка проблеми. В умовах обмеженості власних ресурсів іноземні інвестиції стають фактором зростання регіональної економіки. Інвестиції стимулюють ріст темпів промислового виробництва та валового регіонального продукту - це, у свою чергу, сприяє покращенню соціальних показників розвитку регіону, серед яких найважливішими $\epsilon$ рівень безробіття. Активізація інвестиційної діяльності регіону свідчить про підвищення довіри іноземного бізнесу до влади, $\epsilon$ індикатором успішності проведених внутрішніх реформ, ефективної інвестиційної політики. 3 огляду на вигідне географічне розташування, високий природно-ресурсний потенціал, наявність кваліфікованих кадрів Львівська область вважається одним із найбільш інвестиційно-привабливих регіонів України. Проте, починаючи із 2015 року, спостерігалося незначне зниження інвестиційної активної регіону. Відтак, виникає необхідність здійснення глибокого аналізу інвестиційного процесу в регіоні 3 метою формування ефективної стратегії залучення іноземних інвестицій в його економіку.

Аналіз останніх досліджень $\mathbf{i}$ публікацій. Дослідження інвестиційної діяльності регіонів України та визначення основних викликів ii

(C) Цанько Олександра Олександрівна, аспірант, Львівський регіональний інститут державного управління Національної академії державного управління при Президентові України, провідний спеціаліст відділу міжрегіональної співпраці та протокольного забезпечення управління міжнародного співробітництва та євроінтеграції департаменту міжнародної технічної допомоги та міжнародного співробітництва Львівської облдержадміністрації, тел.: 0994837931, e-mail: sandra493@ukr.net активізації перебуває в центрі уваги таких науковців, як: Деделюк К.Ю. [2], Фарат О.В. [12], Сімків Л.С. [10], Лешанич Л., Гунда С. [4] та ін. В їх роботах висвітлено ключові аспекти розвитку інвестиційної діяльності в регіонах України та визначено актуальні виклики активізації інвестиційної діяльності.

Виділення невирішених раніше частин загальної проблеми. Незважаючи на підвищений інтерес українських науковців до іноземних інвестицій як альтернативного джерела поповнення дефіцитних фінансових ресурсів до сьогодні відсутні грунтовні дослідження, що розкривають особливості інвестиційного середовища, факторів інвестиційної привабливості окремих регіонів України.

Формування цілей статті. Метою статті $\epsilon$ проведення аналізу інвестиційного середовища Львівської області, дослідження основних тенденцій процесу інвестування, факторів інвестиційної привабливості регіону.

Опис основного матеріалу дослідження. Відомо, що активізація інвестиційної діяльності регіону $\epsilon$ рушійною силою зростання обсягів виробництва, підвищення рівня зайнятості населення. Інвестиції створюють підгрунтя для економічного піднесення приймаючої економіки, iii інтеграції у світове господарство на основі розширення виробничих потужностей, передачі інновацій та нових технологій, позитивного досвіду управління. Залучення інвестицій в економіку $\epsilon$ одним із напрямків поглиблення взаємовигідного співробітництва між країнами.

Станом на сьогодні українська економіка не володіє внутрішніми резервами, достатніми для забезпечення фінансами національного господарства в належному обсязі. Відтак, виникає гостра проблема використання дієвих 
методів залучення інвестицій органами влади на місцях для забезпечення регіонального соціально-економічного розвитку. Регіональна інвестиційна політика - це виконання узгодженої 3 державою стратегії по залученню інвестицій, комплекс заходів, в результаті якого очікується покращення основних соціальних-економічних параметрів регіону. 3 огляду на вищенаведене, можна сказати, що інвестиційна політика є невід'ємною частиною економічної політики.

Потенційний інвестор при прийнятті рішення щодо вкладання капіталу в певний проект здійснює комплексну оцінку інвестиційної привабливості на різних рівнях, починаючи від країни загалом, закінчуючи об'єктом капіталовкладень. Сьогодні існує широка класифікація факторів інвестиційної привабливості, які умовно можна поділити на геополітичні, економічні, суспільно-політичні та інформаційні.

Львівщина вважається однією із найбільш інвестиційно привабливих областей України. Регіон має вихід до кордону з СС, іiі територією проходить державний кордон 3 Республікою Польща протяжністю близько 278 км. Завдяки своєму сприятливому географічному розташуванню Львівська область є перехрестям торгівельних шляхів Свропи та Азії, а близькість до державного кордону відкриває перспективи розвитку транскордонного співробітництва. Надра області багаті на кам'яне вугілля, сірку, торф, калійну і кухонну сіль, будівельні матеріали, $\epsilon$ родовища нафти та газу, однак основним ii багатством $\epsilon$ значні запаси лікувальних мінеральних вод [5].

Львівська область має значний кадровий потенціал і здатна забезпечити висококваліфікованими спеціалістами як виробничу, так i невиробничу сферу господарства. Сьогодні на території регіону функціонує понад 60 вищих навчальних закладів I-IV рівня акредитації.

Визначальним фактором для ефективності роботи інвесторів є розвинута інфраструктура, наявність територій, які можна використовувати під реалізацію великих, середніх та малих інвестиційних проектів. За результатами 2017 року в області було відремонтовано близько 600 км доріг на загальну суму понад 3 млрд. грн. 3 огляду на близькість до державного кордону Львівщина має транзитний потенціал. Через регіон проходить 547,9 км доріг міжнародного значення, найбільшими із яких $є$ «М-06 КиївЧоп», «М-11 Львів-Шегині».

Необхідно відзначити, що територією області пролягають міжнародні комунікації, які ведуть до Словаччини, Угорщини, Румунії. Через область проходять три важливі транспортні коридори:

1) із Заходу на Схід: коридор № 3 Берлін Вроцлав - Львів - Київ та коридор № 5 Трієст Любляна - Львів;

2) 3 Півночі на Південь: коридор Гданськ Варшава - Львів - Одеса [7].

Згідно 3 рейтингом інвестиційної привабливості регіонів, складеним Київським міжнародним інститутом соціології у партнерстві 3 Інститутом економічних досліджень та політичних консультацій, у 2014 році Львівська область зайняла перше місце. За основу складових розрахунку були взяті інноваційний потенціал, географічне розташування, інфраструктура, діловий клімат, відкритість влади, природні та трудові ресурси тощо [9].



\section{Рис. 1. Динаміка іноземних інвестицій у Львівській області, млн дол. США* \\ *Складено автором за джерелом [1]}

Проаналізувавши динаміку інвестиційної активності Львівської області за останні сім років, можна зробити висновок, що починаючи із 2010 року до 2014 року спостерігалося помірне зростання обсягу іноземних інвестицій. За результатами 2014 року обсяг залучених інвестицій в економіку регіону склав 1379,5 млн дол. США. Однак, починаючи з 2015 року спостерігалося зниження інвестиційної активності у Львівської області (див. рис. 1).

Дану тенденцію можна пояснити початком бойових дій на Сході країни, що негативно вплинуло на інвестиційну привабливість України та їі імідж загалом.

В трійку лідерів серед іноземних країнінвесторів Львівщини у 2016 році потрапили Польща, Кіпр та Австрійська Республіка.

Польща традиційно впродовж багатьох років виступає як головний інвестор області, що $є$ наслідком високого рівня міжрегіональної та транскордонної кооперації, активного діалогу між владними структурами сторін, представниками бізнесу, виконання спільних 
проектів. Надійним підгрунтям для взаємовигідної співпраці та реалізації вищезазначеного $\epsilon$ взаємна зацікавленість сторін щодо розвитку співробітництва 3 огляду на спільне історичне минуле та наявність спільного кордону. Згідно даних регіональної статистики Львівської області в період 2010-2016 pp. найбільш інвестиційно активними районами області були Жовківський, Городоцький, Сокальський та Яворівський райони.

В період після 2015 року спостерігається зниження інвестиційної активності у всіх зазначених районах крім Пустомитівського (табл. 1).

Динаміка іноземних інвестицій у районах Львівській області, тис. дол. США*

\begin{tabular}{|l|c|c|c|c|c|c|}
\hline \multicolumn{1}{|c|}{ Район } & \multicolumn{7}{c|}{ Piк } \\
\hline \multicolumn{1}{|c|}{} & $\mathbf{2 0 1 1}$ & $\mathbf{2 0 1 2}$ & $\mathbf{2 0 1 3}$ & $\mathbf{2 0 1 4}$ & $\mathbf{2 0 1 5}$ & $\mathbf{2 0 1 6}$ \\
\hline Буський & - & 722,40 & 564,90 & 1582,00 & 2044,90 & 683,60 \\
\hline Городоцький & 2967,80 & 3484,70 & 13659,10 & 1624,10 & - & 2071,80 \\
\hline Жидачівський & 223,70 & - & 536,20 & 108,30 & - & - \\
\hline Кам'янка-Бузький & 22647,90 & 664,20 & 635,20 & 137,20 & - & - \\
\hline Жовківський & 234,90 & 721,10 & 1677,40 & 1647,90 & 277,50 & 3417,50 \\
\hline Миколаївський & - & 297,90 & 257,60 & 279,20 & - & - \\
\hline Пустомитівський & 4751,70 & 1583,50 & 1329,60 & 738,90 & 2007,90 & 916,50 \\
\hline Радехівський & 231,10 & 419,00 & 19518,00 & - & - & - \\
\hline Сокальський & 3112,40 & 6943,30 & 6219,20 & 3271,10 & 5459,00 & 3587,90 \\
\hline Стрийський & 4039,40 & - & 6942,70 & 3838,50 & - & - \\
\hline Яворівський & 275,10 & 722,30 & 400,60 & 420,10 & 19,70 & 1855,00 \\
\hline
\end{tabular}

*Складено автором за джерелом [1]

Львівська область має багатогалузеву структуру економіки, в склад якої входять видобувна галузь (нафта, газ, вугілля), сільське господарство, харчопереробна, будівельна, машинобудівна промисловість, туризм (об'єкти культурної спадщини ЮНЕСКО, санаторії, курорти) та інші, що створює широкі можливості для іноземних капіталовкладень.

У 2016 році на Львівщині спостерігався позитивний тренд створення підприємств 3 іноземним капіталом - на території області запрацювало більше 50 нових підприємств, на яких було створено понад 12 тис. робочих місць. Серед них найвідомішими $є$ :

- ТОВ «Фуджікура аутомотів Україна Львів» - (Яворівський район; виробництво електропроводки для автомобілів);

- ТзОВ «Бадер Україна» - (Яворівський район; виробництво автомобільної шкіри преміум-сегменту;

- ТзОВ «СУКП «Укрлісхолдинг» (Старосамбірський район; виробництво шпону).

Позитивна тенденція збереглася і в 2017 р. в регіоні відкрили понад 80 нових виробничих потужностей, створено понад 8 тис. робочих місць. 3 метою виконання "Стратегії розвитку Львівської області до 2020 року” особлива увага приділяється розвитку сільських територій, зокрема шляхом будівництва виробничих потужностей підприємств у межах сільських територій та стимулювання зарубіжних інвесторів щодо здійснення капіталовкладення у галузь сільського господарства [11]. Яскравим прикладом такої діяльності є відкриття ТзОВ «Галіція Грінері» (Королівство Нідерланди; будівництво теплиць та вирощування салатної продукції потужністю $4600 \mathrm{~m}^{2}$ ).

Також важливе місце посідає розвиток джерел альтернативної енергії. У 2017 році в області відкрили 5 сонячних та 1 вітрову електростанції загальною потужністю 48,8 МВт. Цього року було введено в експлуатацію 95 сонячних установок приватних домогосподарств потужністю 1,3 МВт, сума залучених інвестицій - 1,5 млн євро [5].

У зв'язку із низкою негативних факторів інформаційного та суспільно-політичного характеру, що впливають на інвестиційну привабливість України та іiі регіонів, вітчизняна економіка нарощує обсяги залучення іноземного капіталу досить повільними темпами.

На сучасному етапі проведення внутрішніх реформ в Україні дедалі частіше регіональні ініціативи стають домінантою інтенсифікації економічного зростання, залучення інвестицій. Центральна урядова політика передбачає створення сприятливого інвестиційного клімату в країні загалом.

Незважаючи на кризові явища, які мають місце в українській економіці, Львівщина продемонструвала яскравий приклад того, що інвестування коштів в економічно привабливі проекти та ведення зовнішньоекономічної діяльності на теренах України $є$ ефективним. 
Впродовж останніх років Львівська область сформувала свою стратегію залучення інвестицій.

У січні-березні 2017 року в економіці регіону відбувся приріст сукупного іноземного акціонерного капіталу (3 урахуванням переоцінки, утрат, курсової різниці) на 23,0 млн дол. США, або на 2,1\% відносно початку року. Станом на 1 квітня 2017 року обсяг прямих іноземних інвестицій у розрахунку на одну особу у Львівській області склав 445,1 дол. США (в Україні - 895,2 дол. США).

Упродовж 2017 року в економіку Львівщини іноземними інвесторами вкладено 61,6 млн дол. США, що на 5,2\% більше, ніж у 2016 році. Найбільшими інвесторами були Республіка Польща, Кіпр, Німеччина, Нідерланди, Данія та Австрійська Республіка [1]. Сьогодні одним із дієвих інструментів підвищення інвестиційної та інноваційної активності в багатьох економічно розвинених країнах світу $\epsilon$ функціонування спеціальних промислових зон, або так званих індустріальних парків.

В Законі України «Про індустріальні парки» дається наступне визначення «...індустріальний (промисловий) парк - визначена ініціатором створення індустріального парку відповідно до містобудівної документації облаштована відповідною інфраструктурою територія, у межах якої учасники індустріального парку можуть здійснювати господарську діяльність у сфері переробної промисловості, а також науково-дослідну діяльність, діяльність у сфері інформації і телекомунікацій на умовах, визначених цим Законом та договором про здійснення господарської діяльності у межах індустріального парку» [8].

Станом на 9 січня 2018 року в Україні зареєстровано 28 індустріальних парків. В регіональному розрізі найбільша кількість індустріальних парків зосереджуються у Київській та Львівській області.

Таблиця 2

Інформація про індустріальні (промислові) парки Львівської області, включені до Реєстру індустріальних (промислових) парків станом на 9 січня 2018 року*

\begin{tabular}{|l|l|l|c|}
\hline № & \multicolumn{1}{|c|}{ Найменування індустріального парку } & \multicolumn{1}{|c|}{ Місце знаходження } & $\begin{array}{c}\text { Дата включення } \\
\text { в Ресстр }\end{array}$ \\
\hline $\mathbf{1}$ & Львівський індустріальний парк «Рясне - 2» & $\begin{array}{l}\text { м. Львів, у межах промвузла «Рясне - } \\
\text { 2» }\end{array}$ & 07.02 .2014 \\
\hline $\mathbf{2}$ & Яворівський індустріальний парк & Яворівський район, Львівська область & 26.04 .2017 \\
\hline $\mathbf{3}$ & Кам'янка-Бузький індустріальний парк & м. Кам'янка-Бузька Львівської області & 31.05 .2017 \\
\hline $\mathbf{4}$ & Новороздільський індустріальний парк & м. Новий Розділ Львівської області & 15.06 .2017 \\
\hline $\mathbf{5}$ & Індустріальний парк «СІГМА Парк Яричів» & $\begin{array}{l}\text { с. Старий Яричів, Кам'янка-Бузький } \\
\text { район Львівської області }\end{array}$ & 04.09 .2017 \\
\hline
\end{tabular}

*Складено автором за джерелом [6]

На думку міжнародних консультантів, однією 3 передумов поліпшення інвестиційної привабливості Львівської області та створення конкурентоспроможної економіки, разом із розвитком інфраструктури, є покращення доступу інвесторів у регіон. Львівщина володіє значними земельними ресурсами, вільними земельними ділянками, які можуть бути використані під розміщення індустріальних парків. Створення індустріальних парків $\epsilon$ необхідною формою залучення інвестицій у промислове виробництво i $\epsilon$ механізмом покращення його галузевої структури. Індустріальні парки сприяють входженню до регіонів великих інвесторів, нових технологій, завдяки чому створюються нові робочі місця, зростають надходження до бюджетів усіх рівнів [11, с.49]. Серед основних переваг індустріальних парків можна назвати фінансові та податкові, організаційно-інформаційні стимули.
Одною 3 умов активізації інвестиційної діяльності та економічного зростання на рівні окремих регіонів $є$ проведення децентралізації державної влади, що сприяє підвищенню управлінської компетенції та самостійності регіональних i місцевих органів влади. Однак підвищення самостійності регіонів не гарантує приплив іноземного капіталу. Сьогодні в посилених умовах конкуренції у світовому економічному просторі особливого значення набуває інформованість іноземних інвесторів про соціально-економічний потенціал регіонів та інвестиційні продукти, які вони пропонують. У контексті зазначеного важливим є використання інструментів міжнародного співробітництва, зокрема таких як промоція регіонів.

Промоція інвестицій необхідна для передачі інформації про конкурентоздатність регіональної економіки та про індивідуальні підходи політики залучення прямих іноземних інвестицій. Промоційні заходи включають в себе просування 
інформації для потенційних інвесторів про привабливий імідж місцевості, особливості ведення бізнесу та надання адміністративних послуг майбутнім клієнтам.

Найпопулярнішими заходами 3 промоції інвестицій $є$ : реклама, розсилки, бізнес-семінари, участь у торгових заходах, економічних форумах, виставках, розповсюдження спеціалізованої літератури, цільовий прямий маркетинг, підготовка промо-турів для потенційних інвесторів, організація двосторонніх зустрічей, створення відповідних структур із адміністративного обслуговування (дозволи і т.п.).

Застосуванню вищенаведених заходів передує глибокий аналіз потенційних можливостей регіональної економіки та орієнтація на розвиток тих галузей, які сприятимуть швидкому економічному зростанню, а також для успішного розвитку яких регіон володіє необхідними внутрішніми ресурсами.

Позитивним прикладом $є$ діяльність таких підприємств 3 іноземним капіталом, як «Kragelund Furniture Holding» (виробництво меблів; компанія експортує свою продукцію у 90 країн світу), «Nexans» (компанія-виробник кабельно-провідникової продукції), «Fujikura Automotive Ukraine Lviv» (виробництво оптичного волокна, кабельних джгутів для світових автомобільних марок), ТзОВ «Бадер Україна» (провідний виробник шкіряних сидінь для автомобілів марки «Audi» та «BMW»).

Львівська область завдяки своєму кадровому потенціалу та географічному розташуванню $\epsilon$ привабливим центром для започаткування ITбізнесу.

У Львові функціонують вищі учбові заклади, які щороку випускають понад чотири тисячі висококваліфікованих спеціалістів. Академії та школи при IT-компаніях допомагають студентам та усім охочим опанувати IT-фах, а професійні школи та курси дозволяють перекваліфікуватися для подальшого працевлаштування. Завдяки низці культурних та історичних аспектів, своєму розташуванню, Львівщина дуже споріднена із європейською культурою і типом мислення. Понад третина львівських IT-спеціалістів володіє другою іноземною мовою разом 3 англійською. Розташування міста у самому серці Європи також робить його зручною локацією для аутсорсингу: переліт зі Львова до основних бізнес-центрів Європи в середньому триває до 3 годин. За оцінками експертів даної галузі, щорічний прогнозований приріст галузі становить $20 \%$ [3].

Область пропонує велику кількість досвідчених фахівців, локацій для нових компаній та філій i якісно виконану роботу за вигідними цінами, які роблять Львівщину одним із найбільш конкурентоспроможних європейських ITцентрів.

Висновки i перспективи подальших досліджень. Львівська область як і більшість регіонів України 3 початком бойових дій на Сході відчула зниження інвестиційної активності. На додаток до зазначеного, основними чинниками слабкої інвестиційної діяльності у Львівській області та в Україні загалом $\epsilon$ недосконалість інструментів розкриття внутрішнього потенціалу регіонів, непривабливий інвестиційний клімат, недостатня інформованість іноземних партнерів про безпекову ситуацію на території країни і регіону, зокрема.

Важливими суб'єктивними факторами, які надають інвестиційну перевагу Львівщині у порівнянні із іншими областями, $€$ активна боротьба з корупцією, розвиток інфраструктури, географічне розташування, висококваліфіковані кадри, активне сприяння місцевих органів влади у супроводі інвестиційних проектів та разом 3 тим максимальне невтручання влади у діяльність підприємств.

3 метою розширення господарських зв'язків та ефективного розвитку регіональних економічних систем особливої актуальності набуває потреба покращення інвестиційного середовища областей через розробку комплексу заходів 3 мінімізації впливу визначених факторів, що i буде формувати перспективи подальших досліджень.

\section{ПЕРЕЛІК ВИКОРИСТАНИХ ДЖЕРЕЛ}

1. Головне управління статистики у Львівській області [Електронний ресурс]. - Режим доступу: http://www.lv.ukrstat.gov.ua

2. Деделюк К. Актуальні виклики активізації інвестиційної діяльності регіонів України / К. Деделюк // Науковий вісник Мукачівського державного університету. Сер.: Економіка - 2015. - Вип. 2(2). - С. 133-137.

3. Інформаційний портал Львівського IT Кластеру (Lviv IT Cluster) [Електронний ресурс]. - Режим доступу: http://itcluster.lviv.ua/about-us/about-cluster/

4. Лешанич Л. Розвиток інвестиційної діяльності в Україні та шляхи подолання інвестиційної кризи /Л. Лешанич, С. Гунда // Науковий вісник Ужгородського національного університету. Серія: Право. - 2015. №. 31 (2). - C. 43-45. 
5. Офіційна веб-сторінка Львівської обласної державної адміністрації [Електронний ресурс]. - Режим доступу: http://loda.gov.ua/

6. Офіційна веб-сторінка Міністерства економічного розвитку і торгівлі України [Електронний ресурс]. Режим доступу: http://www.me.gov.ua

7. Офіційний туристичний портал Львівської області [Електронний ресурс]. - Режим доступу: http://lvivregion.travel/ua/cat

8. Про індустріальні парки: Закон України від 21.06.2012 № 5018-VI ВР [Електронний ресурс]. - Режим доступу : http://zakon2.rada.gov.ua/laws/show/5018-17

9. Рейтинг інвестиційної привабливості регіонів 2014/ Київський міжнародний інститут соціології [Електронний ресурс]. - Режим доступу: http://www.ier.com.ua

10. Сімків Л. Стан інвестиційної активності в регіонах України / Л. Сімків // Розвиток продуктових сил i регіональна економіка. - 2016. - Вип. 2. - С. 430-435.

11.Стратегія розвитку Львівської області на період до 2020 року [Електронний ресурс]. - Режим доступу: http://dfrr.minregion.gov.ua/foto/projt_reg_info_norm/2016/05/146_dod_Strategiya_2020.pdf

12. Фарат О. Інвестиційний потенціал Львівщини: стан та оцінка / О. Фарат // Вісник Чернівецького торговельно-економічного інституту. Економічні науки - 2013. - Вип. 2. - С. 154-159.

\section{REFERENCES}

1. Holovne upravlinnia statystyky u Lvivskij oblasti [Electronic resource]. - Access mode: http://www.lv.ukrstat.gov.ua [Main Statistics Office in Lviv region]. [in Ukrainian].

2. Dedeliuk, K. (2015). Aktualni vyklyky aktyvizatsiyi investytsijnoyi diyalnosti rehioniv Ukrayiny / K. Dedeliuk // Naukovyi visnyk Mukachivskoho derzhavnoho universytetu. Ser.: Ekonomika [The challenges of activating investment activity of the regions of Ukraine], the Scientific Bulletin of Mukachevo State University. Ser.: Economics. - Issue 2(2). - Pp. 133-137. [in Ukrainian].

3. Informatsiynyi portal Lvivskoho IT klasteru (Lviv IT Cluster) [Electronic resource]. - Access mode: http://itcluster.lviv.ua/about-us/about-cluster/ [Information portal of Lviv IT Cluster ] [in Ukrainian].

4. Leshanych, L. (2015). Rozvytok investytsiynoyi diyalnosti v Ukrayini ta shliakhy podolannia investytsiynoyi kryzy / L. Leshanych, S. Hunda // Naukovyi visnyk Uzhhorodskoho natsionalnoho universytetu. Seriya: Pravo. [The development of investment activity in Ukraine and ways of overcoming the investment crisis], the scientific bulleting of Uzhhorod National University. Series: Law. - No. 31 (2). - Pp. 43-45. [in Ukrainian].

5. Ofitsijna web-storinka Lvivskoyi oblasnoyi derzhavnoyi administratsiyi [Electronic resource]. - Access mode: http://loda.gov.ua/ [Official web site of Lviv State Regional Administration] [in Ukrainian].

6. Ofitsijna web-storinka Ministerstva ekonomichnoho rozvytku i torhivli Ukrayiny [Electronic resource]. - Access mode: http://www.me.gov.ua[Official web site of the Ministry of Economic Development and Tourism of Ukraine] [in Ukrainian].

7. Ofitsijnyi turystychnyi portal Lvivskoyi oblasti [Electronic resource]. - Access mode: http://lvivregion.travel/ua/cat [Official tourist portal of Lviv region] [in Ukrainian].

8. Pro industrialni parky: Zakon Ukrayiny vid 21.06.2012 No. 5018-VI BP [Electronic resource]. - Access mode: http://zakon2.rada.gov.ua/laws/show/5018-17 [On industrial parks: the Law of Ukraine as of June 21, 2012 No. No. 5018-VI BP][in Ukrainian].

9. Reytynh investytsiynoyi pryvablyvosti rehioniv 2014 / Kyivskyi mizhnarodnyi instytut sotsiolohiyi [Electronic resource]. - Access mode: http://www.ier.com.ua [The rating of investment attractiveness of regions 2014], Kyiv International Sociology Institute [in Ukrainian].

10. Simkiv, L. Stan investytsiynoyi aktyvnosti v rehionah Ukrayiny / L. Simkiv // Rozvytok produktyvnykh syl i rehionalna ekonomika. [The state of investment activity in the regions of Ukraine], The development of productive forces and regional economy. - 2016. - Issue 2. - Pp. 430-435. [in Ukrainian].

11.Stratehiya rozvytku Lvivskoyi oblasti na period do 2020 roku [Electronic resource]. -Access mode: http://dfrr.minregion.gov.ua/foto/projt_reg_info_norm/2016/05/146_dod_Strategiya_2020.pdf [The strategy of Lviv region development for the period until 2020] [in Ukrainian].

12. Farat, O. Investytsiynyi potentsial Lvivshchyny: stan ta otsinka / O. Farat// Visnyk Chernivetskoho torhovelnoekonomichnoho instytutu. Ekonomichni nauky [The investment potential of Lviv region: state and assessment], The bulletin of Chernivtsi Institute of Trade and Economy. -2013. - Issue 2. - Pp. 154-159. [in Ukrainian].

Одержано 07.03.2018 p. 